\title{
SEMINAR KECAMATAN KKLP YAPTI JENEPONTO
}

\author{
ROSTINA \\ 9173770410190
}

sritinawahyuni01@gmail.com

1. Bentuk Kegiatan

> Melaporkan progres program kerja KKLP Yapti Jeneponto pada Seminar Kecamatan.

2. Lokasi

> Aula Kantor Camat Kecamatan Rumbia.

3. Hari/Tanggal dan Waktu

$>$ Senin, 19 oktober 2020 pukul 14:00 - 17:00

4. Peserta yang dilibatkan

$>$ Dosen pembimbing

> Kepala Kantor Camat Rumbia

$>$ Kepala Puskesmas Rumbia

$>$ Ketua STIE dan STKIP Yapti Jeneponto atau yang mewakili

$>$ Ketua Panitia KKLP

> Kapolsek dan Koramil Kecamatan Kelara

$>$ Mahasiswa KKLP Yapti Jeneponto

5. Alasan diadakan

> Alasan diadakannya kegiatan seminar ini adalah untuk melaporkan sudah sejauh mana progres program kerja yang telah dilaksanakan oleh mahasiswa KKLP yang bertempat di Rumbia. 
6. Tujuan dan Manfaat

> Tujuan dan manfaat dilakukannya seminar adalah untuk memaparkan presentasi terlaksananya program kerja di masing-masing desa serta untuk mempererat silaturahmi antar mahasiswa KKLP.

7. Deskripsi Kegiatan

> Kegiatan seminar ini berjalan dengan lancar. Program kerja secara keseluruhan yang ada di kecamatan Rumbia juga sudah mencapai $71 \%$. Tinggal menyelesaikan beberapa program yang belum terlaksana ataupun yang sedang berjalan. 